RJPSS Sept. 2020 Vol. XLV No.2, ISSN: (P)0258-1701 (e)2454-3403 Impact Factor: 7.717

https://doi.org/10.31995/rjpss.2020.v45i01.035

\title{
Inter-Caste Marriage Implications of Social Work Practice, Theory and Research
}

\author{
Dr. Budhabharat Shankarrao \\ Guest Assistant Professor, Dept. of Sociology, \\ Karnataka Folklore University, Gotagodi, \\ Tq Shigaon Dist Haveri, Karnataka, \\ Email:bbbhende@gmail.com
}

Abstract

Marriage in collectivist societies needs to be looking at its contextual issues especially caste locations and caste relationships. Marriage is also seen to be a tool for social control as it is also inherently social and economic at the same time. Marriage norms are followed to protect property relations and to preserve the economic ties between families that enter into such alliances. Explaining marriage in an interdisciplinary context gives a clear view of the need, importance, and role of marriage in the life of the individual and how the institution is changing with changing times. This research paper gives a theoretical review of inter-cast marriage.

Keywords: Inter-caste marriage, Social Work.

Reference to this paper should be

Received: 20.09.2020

Approved: 30.09.2020

Dr. Budhabharat

Shankarrao

Inter-Caste Marriage Implications of Social

Work Practice, Theory and Research

Article No. 35

RJPSS Sept. 2020, Vol. XLV No. 2, pp. 295-303

Online available at: https://anubooks.com/ rjpss-2020-vol-xlv-no-2/

https://doi.org/ 10.31995/

rjpss.2020.v45i01.035 
Inter-Caste Marriage Implications of Social Work Practice, Theory and Research Dr. Budhabharat Shankarrao

\section{Introduction:}

A research study was undertaken in the light of growing and the intentional tussle between the traditional laws strictly imposed by traditional panchayats and the elderly in a caste-based society with regard to issues of marriage. It is surprising and a matter of serious concern that in modern society with massive changes in technology and its mass use, still there is the persistence of the mindsets with respect to rigid adherence of caste laws that seem to defy the laws of the land. This definitely calls for an in-depth understanding of the situation. Attempts to retain hierarchy, power, the act of suppression, and dominance in the name of tradition, caste, marriage, and patriarchy continue in co-existence of adapting to modern lifestyles (Kummar, 1967; Ravinder, 2004). Any act of defying such norms, leads to harsh punishments, which go to such lengths as lynching, killings, rapes, and so on. In understanding marriage, it has been seriously argued by many scholars that an inter-disciplinary framework needs to be adopted. Also, marriage in collectivist societies needs to be looking at its contextual issues especially caste locations and caste relationships. Marriage is also seen to be a tool for social control as it is also inherently social and economic at the same time.

Marriage norms are followed to protect property relations and to preserve the economic ties between families that enter into such alliances. Marriage is not simply a matter of regulating the social ties but the scale in which marriages are held is also seen as reflective of the economic status of the families involved and the more money is splurged the higher the status points one notch up on the social scale. Explaining marriage in an interdisciplinary context gives a clear view of the need, importance, and role of marriage in the life of the individual and how the institution is changing with changing times. There are also gender concerns associated with marriages in India.

These reflect the traditional norms as controlling the sexuality of females, attributing them with secondary status in all forms of marriage as well as within the family(Thapan,1997; Srivatsan, 2000). Marriage is seen to be the desirable goal for girls and hence the concept of Sreedharan which the natal family gives to the girls ( which may be collected from the day the child is born) as a kind of completion of their 'duty towards their girl child'. This is maintained by incurring wedding expenses and the dowry system prevailing in India. However, various theorists (Lundberg, Pollack, 2013) also talk about the weakening of the gendered specific role patterns. With the enhancement of educational opportunities, the availability of wage work for women and also an increase in dowry demands have even led to delayed marriages 
RJPSS Sept. 2020 Vol. XLV No.2, ISSN: (P)0258-1701 (e)2454-3403 Impact Factor: 7.717

https://doi.org/10.31995/rjpss.2020.v45i01.035

(Desai, 2010). Feminist approach to understanding marriage looks at marriage as a gendered institution.

The social context also plays an important role in shaping the institution of marriage. With respect to Hindu Society, this is played through the caste relations and caste contexts. There is caste endogamy with respect to this institution and there is at the same time strict norms of punishment if there is the transgression of the same If marriage is within one's own caste it is accepted universally otherwise it becomes a crime (Kannan, 1963; Shalini, 2009). Thus even in modern times, the traditional social institutions prevail in selecting one's mate. Matrimonial advertisements in newspapers, internet sites play a big role in reinforcing these caste norms (Tridib, 1988; David, 1970). Jati is an endogamous group within which one must marry; members of a jati were part of a descent group traditionally assigned to a specific occupation (Pal, 2004; Chowdhry, 2007). Anyone expressing a choice in selecting one's mate is considered to have committed a sin Character assassination is indulged in by considering such females as having a loose character and males are considered to be either cowards or weak character and such couples are considered to be a dirty fish which can contaminate the whole pond. Jodhka(2013) and Saroja(1999) consider the assertion of rights as a definite a threat to patriarchy, the caste system, social control - control over women, and as a disruption to the socioeco-political sphere of the community.

As a result of this threat, severe punishments- diktats, violence, murders has taken place ever since - especially under the close watch of khap panchayats (Yadav, 2009; Madsen, 1991). Children born of intercaste marriages were seen as having mixed blood and hence low in caste and were denied rights. However, this has been questioned and challenged time and again (Madsen, 1991; Chowdhry, 2007). Hence from all spheres, be it the male - having intercaste marriage, be it the female or even the children born out of intercaste marriage - all were either disowned (from family, society, community) or not recognized well and not respected either. This further proved the rigidity of norms of caste in the society (Saroja, 1999; Kannan, 1963). Secular state in India which considers all religions as equal has both personal laws and secular laws which regulate marriage. Thus Indian state recognizes the relationship between man and woman under various laws of marriage Hindu, Jain, Sikh Muslim laws, and also secular law of intercaste marriage. Thus, to understand the institution of marriage- its structure, need, importance, and functions- in a more comprehensive manner, it is not just socio-religious, traditional spheres but legal cultural economic aspects that need to be understood and studied- all co-existing together. 
Inter-Caste Marriage Implications of Social Work Practice, Theory and Research

Dr. Budhabharat Shankarrao

The Hindu Marriages Disabilities Removal Act (1946) and the Hindu Marriage Validity Act, 1949 were the two landmark Acts that have significantly changed the marriage rules for Hindus. The former permitted Zagora marriages (of same gotra ancestor) and the latter permitted intercaste marriages, amongst Hindus. Apart from certain prohibited degrees of relationship (Sapindus)- seven degrees from the father's side and five degrees from the mother's sidewall other marriages are validated and legal, according to Hindu Marriage Act,1955. These two acts brought about a landmark change in society because it gave more freedom, a legal status, a right to an individual in matters of choice of a partner, and even in matters related to separation and divorce (Diwan,2008).

The Special Marriage Act (1954) gave recognition to the right of the individual to choose his/ her life partner irrespective of caste and religion. Though, some loopholes in this act have been identified to be the procedures (which emphasize writing one's application) and time of one month with proof of residence (Choudhry, 1991). Marriage is a form of Social control. While social control can be 'formal'regulated through laws, rules well defined by institutions and government agencies through punishments, fines, and so on. On the other hand, 'informal' social control can be through socialization, internalization of norms, values, culture, and tradition (Black cited in Innes, 2003). This can be seen in the context of dominant caste groups suppressing the lower caste groups and also women being the controlled by male authority (patriarchy). Social groups exercise social control through the intimate close bondedness of social ties. Hirschi (1969) and Horwitz (1990), indicate the nature of social bonds that emerge from small, intimate, close bondedness, fostered through such concepts as 'attachment', 'commitment' and 'belief'.

These exert a strong sense of and influence of power on framing the attitude, behavior, thought, and actions of the individual- within the family and group. It is in this respect that the shared norms of caste can be understood. Acceptance in the group, fear of rejection shapes human behavior (Coleman, 1990). Primary and secondary socialization shapes one's attitudes and beliefs and in collectivist societies, these are strongly articulated through following caste, village, and marriage norms that this study has shown. In maintaining social ties the individual also internalizes the restrictions and boundaries within which such ties are accepted and exhibited. These internalizing processes are what the concept of morality implies. The individual also internalizes the sentiments of guilt and praise and behavior and action is controlled accordingly. This further can be explained through Gramsci's concept of hegemony (1971) and Althusser's 'ideological state apparatus' theory (1971), which went on to explain how the dominant groups exerted control through their dominant 
RJPSS Sept. 2020 Vol. XLV No.2, ISSN: (P)0258-1701 (e)2454-3403 Impact Factor: 7.717

https://doi.org/10.31995/rjpss.2020.v45i01.035

ideas and behave as repressive state apparatus in regulating behavior, thinking patterns, the belief of the individual and so on. Also, both law and morality act as the push and pull factors in shaping the behavior and action of the individual (Shavell, 2001).

In the context of Western U.P., there have been reports of serious human rights violations because of the role played by caste panchayats in regulating marriage. Even after the statutory panchayats were formed/ established, the traditional panchayats have always tried to assert their autocratic rule. Social control was exercised and is being exercised through regulating the institution of marriage, by ordering harsh punishments as there is a constant need to maintain status and power. The 'power to control the status' thus is the domain of the elders/khaps- against the young couples who plan, wish or intend to marry breaching the caste endogamy rule. Along with this, there is also the 'power to control female sexuality' since in the Hindu society women are treated as 'property' to be taken care of and nurtured (Pal, 2004; Madsen, 1991). Very little statistical data is available on killings, lynching, and murders in the name honor happening in India. And no research studies have been conducted exclusively on this-highlighting it as a social problem. Cases have been reported as mere incidents of crime, like articles, reporting, etc not recognizing it as a growing concern or a social problem.

The study was undertaken in a village, in western UP, District Ghaziabad. The study focused on the nature of relationships pertaining to marriage family and inter-community relations and conflicts. The study also focused on the way caste diktats, village diktats interact and interrogate the larger legal/citizenship and democratic principles and procedures. There was a need to understand the various concerns within the village and how these are further interrogated by the larger political structures located outside the village realm.

The study enabled one to gain an understanding of the entire edifice of caste norms which are the building blocks of marriage. Even when the democratizing tendencies have been sought to be institutionalized through government machinery and this is a rational and planned exercise as part of the welfare state universal well as the agenda and also welfare of marginalized and under-served populations; the state machinery has to interrogate with the questions of caste and gender and other inequalities in the society.

There is tension between these two and is played out in the village in an explicit manner. Thus the protection arm of the state in terms of the police and the administration seems to be in constant turmoil as to what position one has to take 
Inter-Caste Marriage Implications of Social Work Practice, Theory and Research

Dr. Budhabharat Shankarrao

the dominant societal stand or the democratic/citizen-based approach. We also see the work of media and how it responds to these challenges in the raising of such issues of caste and inter-caste marriage, the attempt at building images, and the changes in building images related to women, children, caste, and inter-caste marriages as also democracy itself. The media representations are thus important in socializing the society or reinforcing the norms. The study also focused on the role of media in highlighting these issues.

\section{Locating Family in Social Context:}

It is noted that the Family as an institution influences behavior both in private and public. Thus in terms of Indian society, many scholars have highlighted the joint family system broadly located in the caste system wherein tradition and authority of the elderly male (usually the father is the head of the family) plays a prominent role (Burgess and Locke cited in Patel, 2005. On the contrary, the Companionship family system found in complex societies has small size family units, having two generations (that of parents and children) similar to that of nuclear family there is the erosion of traditional authorities and the male is not the sole decision-maker. Changes in the law have enabled the inheritance rights of women and have impacted on their status. State-supported empowerment programs and opportunities for education and employment opportunities have increased for women that undermine the patriarchal structures located within the family and the larger society. While change is occurring, it is to be noted that it is occurring slowly and gradually and in parts (Ross, 1955). In our society, the family is overpowered by norms, traditions, and patriarchy rule the family structure in our society. On one hand, where the family is regarded as an eternal institution that fulfills the basic needs of the individual- social, psychological, physical, financial, on the other hand, it is also considered as a major source of exploitation of the individual. The social relations, one dominant over the other, exert the power of the stronger ones on the weaker which leads to expectations and exploitation (esp. women/ children or by the parents on their children or the values and norms of the family which is gender-biased or discriminating against females.

With regard to the theoretical perspectives, the researcher used to conflict and feminist perspectives to understand the inter-community relations and the feminist perspective to locate and understand the position of the oppressed be it the women, or the castes lower in the hierarchy. The latter perspective is captured from the articulation of Delphy (1988) who spoke of two modes of production the society one of industrial mode where goods are produced and the second the family model 
RJPSS Sept. 2020 Vol. XLV No.2, ISSN: (P)0258-1701 (e)2454-3403 Impact Factor: 7.717

https://doi.org/10.31995/rjpss.2020.v45i01.035

where domestic services child-rearing are undertaken. Whereas the first leads to capitalist exploitation the second leads to familial or patriarchal exploitation.

\section{Impications of Social Work Practice, Theory, And Research:}

Researching in the conflict-ridden area takes an enormous amount of time and energy. There is a constant need for

- Discussing, sharing views and opinions, and collecting information on such a sensitive topic, building good rapport and trust with the people in general and the respondents, in particular, were key points that were taken good care of. The researcher also needs to cope with emotional trauma. One can seek large-scale support mechanisms, strong authoritarian structure, or even see democracy at.

- Authoritarian model to deal with situations/ problems where human rightsthe right to life and dignity is threatened only to save family and caste honor. For example- during the time when widows were burnt alive on the funeral pyre of their husbands, Sati Prevention Act was passed in 1987 which was not only punishable for the ones who committed the crime or forced for the same but also those who glorified or supported it. Such a strong rule/ law was not only formed but implemented and this positioning, advocacy needs to be strengthened for dealing with crimes, punishments, diktats against couples who choose to marry outside their caste. Though this topic is not unknown completely, but what needs to be understood/ highlighted is the fact that.

- Despite the talk of democratic institution, human rights violation continues to exist and at an increasing pace. Social work is to recognize it as a social problem. Also as to how a research is done in such an area about such a sensitive topic, a series of studies can commence with a motive of spreading awareness and knowledge about the Special Marriage Act and Inter-caste Marriage on the line of action research. It has also been observed that this entire area of an institution of marriage is a neglected area by social workers.

- Marriage has been understood from law-related studies, the perspective of sociology and psychology but social work has the biggest advantage of studying inter-caste marriage from a combination of perspectives. Social workers can also engage in advocacy to implement helpline and support systems for the couples and families who undergo inter-caste marriage. An attempt can be made to incorporate in the school text negating the influence of those who are protecting tradition at the cost of the lives of their own 
Inter-Caste Marriage Implications of Social Work Practice, Theory and Research

Dr. Budhabharat Shankarrao

children. It is important to bring it in the open and take it up as a human rights issue at various levels.

- Sensitization workshops for all administrative and police personnel need to be undertaken continually.

\section{References:}

1. Bhatia, A. (2009), Honour Killing- A Study of the Causes and Remedies in its Socio-Legal Aspect, International Indexed \& Referred Research Journal, Vol4(38).

2. Buhler, G. (1886). Sacred Books of the East: The Laws of Manus (Vol. XXV). Oxford.

3. Caste system ruins country, intercaste marriages important for progress: SC Indian Express (India), July 8, 2006, 2pp

4. Chakrabarti, A. and Srivatsan, R. (2000), Conditions of visibility: Writings on photography in contemporary India (Gender Culture Politics Series). Calcutta: STREE Publications.

5. Chakraborti. Tridib. (1988). Recent Trends in Hindu Marriage (A Sociological Study on Calcutta)

6. Choudhary, K. (1991), "Anatomy of the Special Marriage Act”, Economic and Political Weekly, Vol. XXVI, No. 52.

7. Chowdhry, Prem. (2007). Contentious Marriages, Eloping Couples: Gender, Caste, and Patriarchy in Northern India. New Delhi. Oxford University Press.

8. Clausen, John A. (ed.) (1968) Socialization and Society, Boston: Little Brown and Company.

9. Delphy, C. (2010), Patriarchy, Domestic Mode of Production, Gender, and Class.

10. Desai, S. (2010), Gender Scripts and Age at Marriage in India, Demography, Vol. Aug; 47(3): 667-687

11. Deshpande and Poona, C.G. (1972) 'On intercaste marriage; an empirical research work'.

12. Diwan, P. (2008). Modern Hindu Law. Nineteenth Edition: Concept of Marriage, 63-68; Marriage, 92-96. Allahabad: Allahabad Law Agency.

13. Dr. Ambedkar, Babasaheb. (1944). Annihilation of castes. Writing and Speeches.

14. Dumont, Louis. ( 1966). Homo Hierarchicus : The Caste System and Its Implications. Walton Street, Oxford University Press.

15. Earle, L. et al. (1999), Social Context Theory, South Pacific Journal of Psychology. 
RJPSS Sept. 2020 Vol. XLV No.2, ISSN: (P)0258-1701 (e)2454-3403 Impact Factor: 7.717

https://doi.org/10.31995/rjpss.2020.v45i01.035

16. Grabowski, R. (2008) 'Modernization, inter-caste marriage, and dowry: An analytical perspective', Journal of Asian Economics. 20(1):69-76 DOI: 10.1016/ j.asieco. 2008.07.001

17. Gramsci, Antonio. (1971).Selections from the Prison Notebook: International Publishers, New York.

18. Grewal, P.K., Honour Killings and Law in India, Department cum Centre for Women's Studies and Development, Panjab University Chandigarh, India.

19. Grover, Shalini. (2009). Lived Experiences: Marriage, Notions of Love, and kinship support amongst poor women in Delhi. Contributions to Indian Sociology. Retrieved from http://cis.sagepub.com/cgi/content/abstract/43/1/1 